\title{
eTourism for Socio-Economic Development
}

\author{
Alessandro Inversini ${ }^{*}$ Isabella Rega ${ }^{* *}$
}

\begin{abstract}
Tourism has often been described as an economic driving force that contributes to rural and emerging economies development. However, when it comes to the social aspect of development the nature of this contribution is still debated by academics. Information and Communication Technologies can help enhancing the socio-economic contribution of tourism by fostering community-based tourism independent marketing and sales dis-intermediation.

eT4D can be defined as the independent use of technologies by micro and small community based tourism firms to market and sell their products and services thus fostering local socio-economic development.
\end{abstract}

Keywords: ICT; Socio-Economic Development; eTourism4Development; Global Tourism; Global Competition

\section{Tourism Industry and ICT}

Tourism is considered as a potential strategic factor for economic growth (Blake, Arbache, Sinclair, \& Teles, 2008; Stabler, Papatheodorou \& Sinclair, 2009). It is actually seen as an economic driving force in many developing countries as it substantially contributes to the GDPs of many emerging economies (e.g. from the roughly $9 \%$ in Ethiopia or Senegal rising to $25 \%$ in Mauritius - Sireyjol, 2010). However, there is a lively discussion about the nature of the tourism contribution to social aspects of development. Tourism generates new businesses, improves infrastructures and services, fosters preservation of the natural environment/landscapes and helps with economic diversification (Herrero \& San Martín, 2012; Wang \& Pfister, 2008). Despite this, tourism has also a controversial effect on natural resources and hosting communities' exploitation (Deller, 2010) by international investors and enterprises. Although scientific work addressing the issue of socio-economic development in tourism does exists (e.g. Lea, 2006; Scheyvens, 2002; Sharpley \& Telfer, 2014; Ezeuduji, 2015), the common vision of tourism in developing contexts is that local communities are disempowered and their resources aliened by international tourism development (Ashley, 2000). Western tourism companies seem to dominate in these contexts due to marketing and capital power (Cater, 1995). For example the role of big tour operators was seen in the past as oligopolistic due to the possibility of these large companies to

\footnotetext{
* Senior Lecturer in Management, Bournemouth University (ainversini@bournemouth.ac.uk)

** Senior Lecturer in Education and Digital Literacies, Bournemouth University (irega@bournemouth.ac.uk)
} 
shift large mass of customers from one country to another, thus affecting the overall tourism supply chain (Akama, 1999). Therefore, some authors, adopted an imperialistic and post-colonial vision of tourism (Nash, 1989; Pastran, 2014), and questioned the actual quality of the growth that tourism generates (Hall, 2007) or argued that tourism can generate a general exploitation of the working poor by the rich (Marcouiller, 1997). However, thanks to two main factors, namely (i) the intrinsic nature of the tourism industry, populated by micro and small players, and (ii) the rise of Information and Communication Technologies (ICTs), this vision can be challenged (Gössling, 2016; Szopiński \& Staniewski, 2016)

On the one side, the tourism industry is populated and operated by a galaxy of (micro) Small and Medium size Enterprises (SMTEs), constituting the "life blood" of travel industry (Thomas, Shaw, \& Page, 2011). Furthermore, in developing contexts, research also fussed on the contribution of Micro and Small Tourism Enterprises (MSTEs) to the actual tourism value chain (Kirsten \& Rogerson, 2002). Looking at developing and emerging economies, on a community level, SMTEs and MSTEs can create virtuous socio-economic development (Simpson, 2008) for the actual communities and for the overall tourism supply chain (Kirsten \& Rogerson, 2002). Community involvement in tourism activities was firstly discussed by Murphy (1985) who introduced the concept of Community Based Tourism (CBT). CBT emphasises the inclusive participation of communities in tourism initiatives to ensure economic returns to the locals (Murphy, 2012) and promote the socio-economic evolution of rural and developing areas (Heeks, 2010).

On the other side, The disruptive rise of Information and Communication Technologies (ICTs - Rieple \& Pisano, 2015) is leading the digitalization of the tourism sector (Buhalis, 2003), and is contributing to reach the Millennium Developments Goals (Richard Heeks \& Molla, 2009). Literature acknowledges the impact of ICTs and especially the internet in the tourism field with a stream of research dealing with eTourism (Buhalis, 2003). Furthermore, thanks to the slow but progressive overcoming of the digital divide (Kleine \& Unwin, 2009) ICTs are seen to play a crucial role in socio-economic development with the rise of a specific field of research called ICT4D (Information and Communication Technologies for Development - Unwin \& Unwin, 2009).

Therefore, grounded on the CBT perspective, this research note argues that community owned tourism initiatives can benefit from the use of ICTs, to foster independent marketing and selling activities, thus triggering socio-economic development. An effective use of ICTs by SMTEs and MSTEs in developing contexts can enhance firms' visibility and competitiveness and, therefore, improve the socio-economic conditions of local communities. This field of research is here summarized with the acronym eT4D (eTourism 4 Development) and it sits in the intersections among (i) development studies, (ii) tourism studies and (iii) ICTs. In order to better describe eT4D the following paragraph will present the abovementioned intersections. 


\section{Mapping the Intersections among Development, Tourism and ICT}

\subsection{Tourism Studies and Development Studies}

Literature presents an ever-growing corpus of researches about the intersection between development studies and tourism studies (Sharpley \& Telfer, 2014). Academics acknowledge that the imperialistic and post-colonialist (Nash, 1989; Pastran, 2014) approach of international tourism players in developing countries generates an exploitation of the working poor by the rich (Marcouiller, 1997). Exploitative tourism was historically challenged (Krippendorf, 2010) and alternative forms arose with a renewed focus on local sustainability and community development. Alternative tourism is an ideologically different form of tourism that is considered preferable to mass, consumer-driven and exploitative travel (Wearing, 2001). This is connected with the rise of alternative markets, which include sustainable tourism (Hunter, 1997), ecotourism (Erlet Cater, 1993), ethical tourism (Weeden, 2002), and volunteer tourism (Uriely, Reichel, \& Ron, 2003). These are driven by a growing demand for products and services that are more sustainable, pro-poor, and less harmful to local environments and communities (Callanan \& Thomas, 2005). Alternative tourism is often coupled with Community Based Tourism (Murphy 1985; Simpson, 2008) that is a bottom up approach to involve community in the creation and execution of tourism products (Sebele, 2010). Community participation is often regarded as one of the most essential tools to drive tourism towards a substantial contribution to the local, regional and national development of a country (Lea, 2006). When the community fully participates in tourism activities there is sustainability (Woodley, 1993), better opportunities for local people to gain benefits from tourism taking place in their locality, positive local attitudes and the conservation of local resources (Tosun, 2006).

\subsection{Tourism Studies and ICT}

ICTs have revolutionized the structure and organization of the tourism industry (Poon, 1993). Additionally, the advent of the internet produced a paradigm shift in the industry thanks to the convergence among informatics, communication, and multimedia (eTourism - Buhalis 2003). ICTs and especially the internet, enabled tourism organizations to create personalized marketing campaigns (Buhalis, 2000) and to sell their experiences without intermediaries (Law, 2009). Furthermore, all players within the tourism value chain can be connected thus enabling an effective management of products and services (Zhang, Song, \& Huang, 2009). This vision challenges the one of Cater (1995) ad the one of Akama (1999) who were describing an oligopolistic scenario dominated by big tour operators and travel agencies determining the visitation to the destinations. Thanks to the advancements of technologies peripheral tourism firms, that are outside the popular distribution channels, can have a virtual size (Spencer, Buhalis, \& Moital, 2012), that is to say to be visible and bookable by travellers. However, the access to peripheral areas is often problematic both physically and electronically (Hall \& Page, 2014; Nash \& Martin, 2003). Less developed tourism areas are subject to disparity in technological access (Minghetti and Buhalis, 2009). Therefore, also in these contexts, tourism firms need to enhance their visibility (Lituchy \& Rail, 2000) 
towards a rising share of the market that is increasingly relying on the internet for travel search and purchase (Morrison \& Thomas, 1999).

\subsection{Development and ICT}

With the advent of ICTs and the rise of the internet, development specialists and practitioners started to reflect on how to use these tools to support socio-economic development processes. Thus, in the last decade (Heeks, 2010; Unwin, 2009) a new interdisciplinary field of research emerged, that is the one of ICT4D (Information and Communication for Development). ICT4D brings together computer scientists and social scientists tackling a broad range of developmental domain, such as agriculture, health, education and political participation (Unwin, 2009). The underpinning is that access to digital technology can promote social and economic development (Rega, Vannini, Fino, \& Cantoni, 2013) thus helping in reaching the Millennium Development Goals (Heeks, 2008) and supporting the Post-2015 Development Agenda. Although, there is a lack of studies focusing on tourism (VanZyl, Inversini, \& Rega, 2015) an interesting set of works focuses on entrepreneurship and suggests micro-small and medium size enterprises as unit of analysis (Heeks, 2010) to investigate the intertwine between technologies and development (Kleine \& Unwin, 2009). Within these studies, ICTs are seen to generate benefits related for example to the interaction between customers and suppliers (Donner \& Escobari, 2010) or to enhance the labour productivity leading to higher salaries (Esselaar, Stork, Ndiwalana, \& Deen-Swarray, 2006).

\section{The Missing Piece: eTourism For Development}

The above-discussed intersection among Development, Tourism and ICT clearly describes three distinct research areas in which academies have been engaging in the past years. However, when pulling together the research areas, there is a missing piece that refers to the intersection among all the three above mentioned disciplines; this is where eTourism for Developments (eT4D) sits on a theoretical level.

eT4D conceptualizations builds upon the following concepts:

- The Community Base Tourism perspective (Murphy, 1985; Simpson, 2008; Sebele, 2010) where tourism is driven by the local community with a bottom up approach leading to socio-economic development (Lea, 1988);

- The disruptive rise of ICTs and the internet in the field of tourism and its the impact on both (i) new and personal marketing practices (Buhalis, 2003) and (ii) distribution disintermediation (Law, 2009). of the travel and tourism operators;

- The importance of technologies for socio-economic development and local empowerment (ICT4D - Unwin 2009), given by their role in boosting entrepreneurship (Heeks 2010). 
Merging these three perspectives, tourism can contribute in disrupting its imperialistic and post colonialist tradition in developing countries (Nash, 1989; Pastran, 2014) by giving access to the global market to community owned tourism initiatives. Community based and alternative touristic firms (Bimonte \& Faralla, 2012) have the unprecedented opportunity to promote and sell their products online without intermediaries (Law, 2009). This can foster the growth of community based tourism initiatives and enhance the economic and social status of local entrepreneurs and collaborators thus generating better living conditions in disadvantaged communities.

\section{Conclusion and Emerging Issues}

This note contributes to the body of knowledge about CBT, eTourism and ICT4D, by shading light on the intersection among these domains. It gives a theoretical lens to approach the ever-growing technology adoption by micro and small tourism firms in developing countries.

It is here argued that the disruptive rise of technology can contribute in questioning the imperialistic and post-colonial (Nash, 1989; Pastran, 2014) vision of tourism in developing countries by empowering community based tourism businesses in marketing and selling their products without intermediaries (Buhalis, 2003; Law, 2009). The late nineties vision, based on the oligopolistic marketing and capital power of few organizations (Cater, 1995; Akama, 1999) is here challenged due to the increasing availability and accessibility of technology to micro small and medium enterprises (Brondoni, 2014).

Ultimately, this paper connects technology usage by community lead micro and small tourism firms with the possibility of generating socio-economic development at local level in line with the study of Heeks (2010). This enables community based tourism firms entrepreneurs to be 'on the map' and therefore to find their virtual size (Spencer et al., 2012). Furthermore, the whole supply chain of community based tourism initiatives can benefit at socio-economic level by these technology advancements. This is due to the galaxy of micro and small enterprises contributing to the tourism ecosystem in at community level in developing contexts (Kirsten \& Rogerson, 2002). Therefore, given the nature of the issue at stake, the socioeconomic benefit can relapse both on the experience provider and on the supply chain members. Exploring this new interdisciplinary field is going to generate a deep understanding of current technological practices of micro and small tourism enterprises in developing contexts and of the interconnection among tourism supply chain players.

\section{Bibliography}

Akama, J. S. (1999). The Evolution of Tourism in Kenya. Journal of Sustainable Tourism, 7(1), 625. http://doi.org/10.1080/09669589908667324 
Ashley, C. (2009, February 27). The Impacts of Tourism on Rural Livelihoods [Research/academic paper]. $\quad$ Retrieved November $\quad 14, \quad 2014, \quad$ from http://dspace.africaportal.org/jspui/handle/123456789/22916

Bimonte, S., \& Faralla, V. (2012). Tourist types and happiness a comparative study in Maremma, Italy. Annals of Tourism Research, 39(4), 1929-1950.

http://doi.org/10.1016/j.annals.2012.05.026

Blake, A., Arbache, J. S., Sinclair, M. T., \& Teles, V. (2008). Tourism and poverty relief. Annals of Tourism Research, 35(1), 107-126. http://doi.org/10.1016/j.annals.2007.06.013

Brondoni, S. M. (2014). Ouverture de 'Global Networks and Sustainable Development-1. Symphonya. Emerging Issues in Management, (1), 1-9.

http://dx.doi.org/10.4468/2014.1.01ouverture

Buhalis, D. (2000). Marketing the competitive destination of the future. Tourism Management, 21(1), 97-116. http://doi.org/10.1016/S0261-5177(99)00095-3

Buhalis, D. (2003). ETourism : information technology for strategic tourism management. Harlow, England: Financial Times Prentice Hall.

Callanan, M., \& Thomas, S. (2005). Volunteer tourism: Deconstructing volunteer activities within a dynamic environment. In Niche tourism: Contemporary issues, trends and cases (pp. 183-200). Oxford: Butterworth-Heinemann.

Cater, E. (1993). Ecotourism in the third world: problems for sustainable tourism development. Tourism Management, 14(2), 85-90.

http://doi.org/10.1016/0261-5177(93)90040-R

Cater, E. (1995). Consuming Spaces: Global Tourism. In J. Allen and C. Hamnet (eds), A Shrinking World?Global Unevenness and Inequality (Milton Keynes, pp. 183-231). Oxford: Oxford University Press.

Deller, S. (2010). Rural poverty, tourism and spatial heterogeneity. Annals of Tourism Research, 37(1), 180-205.

http://doi.org/10.1016/j.annals.2009.09.001

Donner, J., \& Escobari, M. X. (2010). A review of evidence on mobile use by micro and small enterprises in developing countries. Journal of International Development, 22(5), 641-658. http://doi.org/10.1002/jid.1717

Esselaar, S., Stork, C., Ndiwalana, A., \& Deen-Swarray, M. (2006). ICT usage and its impact on profitability of SMEs in 13 African Countries. In International Conference on Information and Communication Technologies and Development, 2006. ICTD '06 (pp. 40-47). http://doi.org/10.1109/ICTD.2006.301836

Ezeuduji, I. O. (2015). Strategic event-based rural tourism development for sub-Saharan Africa. Current Issues in Tourism, 18(3), 212-228.

http://doi.org/10.1080/13683500.2013.787049

Gössling, S. (2016). Tourism, information technologies and sustainability: an exploratory review. Journal of Sustainable Tourism, O(0), 1-18.

http://doi.org/10.1080/09669582.2015.1122017

Hall, C. M. (2007). Tourism Planning: Policies, Processes and Relationships. Pearson Education.

Hall, C. M., Prof, P. and H. of the C. for T. C. M. H., \& Page, S. J. (2014). The Geography of Tourism and Recreation: Environment, Place and Space 4th Edition: Environment, Place and Space. Routledge.

Heeks, R. (2008). ICT4D 2.0: The Next Phase of Applying ICT for International Development. Computer, 41(6), 26-33.

http://doi.org/10.1109/MC.2008.192

Heeks, R. (2010). Do information and communication technologies (ICTs) contribute to development? Journal of International Development, 22(5), 625-640. http://doi.org/10.1002/jid.1716 
Heeks, R., \& Molla, A. (2009). Compendium on impact assessment of ICT-for-development projects (Working Paper). Technology \& Social Change Group. Retrieved from https://digital.lib.washington.edu/researchworks/handle/1773/25541

Herrero, Á., \& San Martín, H. (2012). Developing and testing a global model to explain the adoption of websites by users in rural tourism accommodations. International Journal of Hospitality Management, 31(4), 1178-1186.

http://doi.org/10.1016/j.ijhm.2012.02.005

Hunter, C. (1997). Sustainable tourism as an adaptive paradigm. Annals of Tourism Research, 24(4), $850-867$.

http://doi.org/10.1016/S0160-7383(97)00036-4

kirsten, M., \& Rogerson, C. M. (2002). Tourism, business linkages and small enterprise development in South Africa. Development Southern Africa, 19(1), 29-59.

http://doi.org/10.1080/03768350220123882

Kleine, D., \& Unwin, T. (2009). Technological Revolution, Evolution and New Dependencies: what's new about ict4d? Third World Quarterly, 30(5), 1045-1067.

http://doi.org/10.1080/01436590902959339

Krippendorf, J. (2010). Holiday Makers. Taylor \& Francis.

Law, R. (2009). Disintermediation of hotel reservations: The perception of different groups of online buyers in Hong Kong. International Journal of Contemporary Hospitality Management, 21(6), 766-772.

http://doi.org/10.1108/09596110910976007

Lea, J. (2006). Tourism and Development in the Third World. Routledge.

Lituchy, T. R., \& Rail, A. (2000). Bed and Breakfasts, Small Inns, and the Internet: The Impact of Technology on the Globalization of Small Businesses. Journal of International Marketing, 8(2), 86-97.

http://doi.org/10.1509/jimk.8.2.86.19625

Marcouiller, D. W. (1997). Toward Integrative Tourism Planning in Rural America. Journal of Planning Literature, 11(3), 337-357.

http://doi.org/10.1177/088541229701100306

Minghetti, V., \& Buhalis, D. (2009). Digital Divide in Tourism. Journal of Travel Research. http://doi.org/10.1177/0047287509346843

Morrison, A., \& Thomas, R. (1999). The future of small firms in the hospitality industry. International Journal of Contemporary Hospitality Management, 11(4), 148-154. http://doi.org/10.1108/09596119910263531

Murphy, P. E. (1985). Tourism: A community approach (Methuen). London -England.

Nash, R., \& Martin, A. (2003). Tourism in peripheral areas-the challenges for northeast Scotland. International Journal of Tourism Research, 5(3), 161-181.

http://doi.org/10.1002/jtr.426

Nash,, D. (1989). Tourism as a form of imperialism. Hosts and guests: The anthropology of tourism. Hosts and Guests: The Anthropology of Tourism, 2, 37-52.

Pastran, S. H. (2014). Volunteer Tourism: A Postcolonial Approach. USURJ: University of Saskatchewan Undergraduate Research Journal, 1(1).

Poon, A. (1993). Tourism, Technology and Competitive Strategies. CABI.

Rega, I., Vannini, S., Fino, E., \& Cantoni, L. (2013). Exploring the Meanings of Community Multimedia Centers in Mozambique: A Social Representation Perspective. Information Technologies \& International Development, 9(4), pp. 35-54.

Rieple, A., \& Pisano. (2015). Business Models in a New Digital Culture: The Open Long Tail Model. Symphonya. Emerging Issues in Management, 2, 75-88.

Scheyvens, R. (2002). Tourism for Development: Empowering Communities. Pearson Education. 
Sebele, L. S. (2010). Community-based tourism ventures, benefits and challenges: Khama Rhino Sanctuary Trust, Central District, Botswana. Tourism Management, 31(1), 136-146.

http://doi.org/10.1016/j.tourman.2009.01.005

Sharpley, R., \& Telfer, D. J. (2014). Tourism and Development: Concepts and Issues (2nd Edition). Channel View Publications.

Simpson, M. C. (2008). Community Benefit Tourism Initiatives-A conceptual oxymoron? Tourism Management, 29(1), 1-18.

http://doi.org/10.1016/j.tourman.2007.06.005

Sireyjol, D. (2010). Tourism in developing countries: a neglected lever of growth despite its potential. Private Sector Development, 7(25), 25-29.

Spencer, A. J., Buhalis, D., \& Moital, M. (2012). A hierarchical model of technology adoption for small owner-managed travel firms: An organizational decision-making and leadership perspective. Tourism Management, 33(5), 1195-1208. http://doi.org/10.1016/j.tourman.2011.11.011

Stabler, M. J., Papatheodorou, A., Sinclair, M. T., \& Sinclair, T. R. C. D. of E. and C. B. S. M. T. (2009). The Economics of Tourism. Routledge.

Szopiński, T., \& Staniewski, M. W. (2016). Socio-economic factors determining the way e-tourism is used in European Union member states. Internet Research, 26(1), 2-21.

http://doi.org/10.1108/IntR-03-2014-0065

Thomas, R., Shaw, G., \& Page, S. J. (2011). Understanding small firms in tourism: A perspective on research trends and challenges. Tourism Management, 32(5), 963-976. http://doi.org/10.1016/j.tourman.2011.02.003

Tosun, C. (2006). Expected nature of community participation in tourism development. Tourism Management, 27(3), 493-504.

http://doi.org/10.1016/j.tourman.2004.12.004

Unwin, T., \& Unwin, P. T. H. (2009). ICT4D: Information and Communication Technology for Development. Cambridge University Press.

Uriely, N., Reichel, A., \& Ron, A. (2003). Volunteering in tourism: additional thinking. Special Issue: Volunteer Tourism, 28(3), 57-62.

VanZyl, I. J., Inversini, A., \& Rega, I. (2015). The representation of voluntourism in search engines: The case of South Africa. Development Southern Africa, 32(3), 333-349. http://doi.org/10.1080/0376835X.2015.1010714

Wang, Y. (Alex), \& Pfister, R. E. (2008). Residents' Attitudes Toward Tourism and Perceived Personal Benefits in a Rural Community. Journal of Travel Research, 47(1), 84-93. http://doi.org/10.1177/0047287507312402

Wearing, S. (2001). Volunteer Tourism: Experiences That Make a Difference. CABI.

Weeden, C. (2002). Ethical tourism: An opportunity for competitive advantage? Journal of Vacation Marketing, 8(2), 141-153. http://doi.org/10.1177/135676670200800204

Woodley, A. (1993). Tourism and sustainable development: the community perspective. In Tourism and sustainable development Monitoring, planning, managing (J. G. Nelson, R. Butler, \& G. Wall, pp. 135-147). Waterloo: University of Waterloo, Heritage Resources Centre.

Zhang, X., Song, H., \& Huang, G. Q. (2009). Tourism supply chain management: A new research agenda. Tourism Management, 30(3), 345-358.

http://doi.org/10.1016/j.tourman.2008.12.010 